\title{
APPLICATION OF SIMULATED ANNEALING IN SIMULATION AND OPTIMIZATION OF DRYING PROCESS OF Zea mays MALT
}

\author{
MARCO A. C. BENVENGA ${ }^{1}$, SIDNEI A. DE ARAÚJO², ANDRÉ F. H. LIBRANTZ ${ }^{3}$, \\ JOSÉ C. C. SANTANA ${ }^{4}$, ELIAS B. TAMBOURGI ${ }^{5}$
}

\begin{abstract}
Kinetic simulation and drying process optimization of corn malt by Simulated Annealing (SA) for estimation of temperature and time parameters in order to preserve maximum amylase activity in the obtained product are presented here. Germinated corn seeds were dried at $54-76^{\circ} \mathrm{C}$ in a convective dryer, with occasional measurement of moisture content and enzymatic activity. The experimental data obtained were submitted to modeling. Simulation and optimization of the drying process were made by using the SA method, a randomized improvement algorithm, analogous to the simulated annealing process. Results showed that seeds were best dried between $3 \mathrm{~h}$ and $5 \mathrm{~h}$. Among the models used in this work, the kinetic model of water diffusion into corn seeds showed the best fitting. Drying temperature and time showed a square influence on the enzymatic activity. Optimization through SA showed the best condition at $54{ }^{\circ} \mathrm{C}$ and between $5.6 \mathrm{~h}$ and $6.4 \mathrm{~h}$ of drying. Values of specific activity in the corn malt were found between $5.26 \pm 0.06 \mathrm{SKB} / \mathrm{mg}$ and $15.69 \pm 0,10 \%$ of remaining moisture.
\end{abstract}

KEYWORDS: simulated annealing, Zea mays, drying curves, optimization, simulation.

\section{APLICAÇÃO DO SIMULATED ANNEALING NA SIMULAÇÃO E OTIMIZAÇÃO DO PROCESSO DE SECAGEM DO MALTE DE Zea mays}

RESUMO: Este trabalho objetivou a simulação da cinética e a otimização do processo de secagem do malte de milho por meio da técnica Simulated Annealing (SA), para estimação dos parâmetros de temperatura e tempo, tais que mantenham a atividade máxima das enzimas amilases no produto obtido. Para tanto, as sementes de milho germinadas foram secas entre $54-76^{\circ} \mathrm{C}$, em um secador convectivo de ar. De tempo em tempo, a umidade e a atividade enzimática foram medidas. Esses dados experimentais foram usados para testar os modelos. A simulação e a otimização do processo foram feitas por meio do método SA, um algoritmo de melhoria randômica, análogo ao processo de têmpera simulada. Os resultados mostram que as sementes estavam secas após $3 \mathrm{~h}$ ou $5 \mathrm{~h}$ de secagem. Entre os modelos usados, o modelo cinético de difusão da água através das sementes apresentou o melhor ajuste. $\mathrm{O}$ tempo e a temperatura de secagem mostraram influência quadrática sobre a atividade enzimática. A otimização usando SA mostrou que a melhor condição de processo foi quando se trabalhou a $54^{\circ} \mathrm{C}$ e entre $5,6 \mathrm{~h}$ e $6,4 \mathrm{~h}$. No malte produzido, foram encontrados valores da atividade específica de 5,26 $\pm 0,06 \mathrm{SKB} / \mathrm{mg}$ e umidade residencial de $15,69 \pm 0,10 \%$.

PALAVRAS-CHAVE: Simulated annealing, Zea mays, curvas de secagem, otimização, simulação.

\footnotetext{
${ }^{1}$ Bacharel em Ciência da Computação, Programa de Pós-Graduação em Engenharia de Produção, UNINOVE, São Paulo - SP, Fone: (0XX11) 3665-9355, mrentn100@ gmail.com. Bolsista Mestrado PROSUP/CAPES.

${ }^{2}$ Bacharel em Processamento de Dados, Prof. Titular, Programa de Pós-Graduação em Engenharia de Produção, UNINOVE, São Paulo - SP.

${ }^{3}$ Bacharel em Física, Prof. Titular, Programa de Pós-Graduação em Engenharia de Produção, UNINOVE, São Paulo - SP.

${ }^{4}$ Bacharel em Química Industrial, Prof. Titular, Programa de Pós-Graduação em Engenharia de Produção, UNINOVE, São Paulo SP.

${ }^{5}$ Eng $^{\mathrm{o}}$ Químico, Prof. Livre-Docente, Faculdade de Engenharia Química, UNICAMP, Campinas - SP.

Recebido pelo Conselho Editorial em: 5-8-2010

Aprovado pelo Conselho Editorial em: 31-5-2011
} 


\section{INTRODUCTION}

Drying is used in some countries to preserve the product quality, especially in food and pharmaceutical industries. It is defined as the removal of volatile substances (commonly but not exclusively, water) from a solid product, or as a transaction in which the water activity of a product is decreased by water removal through evaporation (BIAZUS et al., 2006a; OMID et al., 2009; PHOUNGCHANDANG et al., 2008; SANTOS \& SILVA, 2008; SIMAL et al., 2005). In drying processes, it is necessary that the final product present reduced internal moisture, to avoid microorganism contamination and preserve the product for a longer time (shelf life) (CAI \& CHEN, 2008; CHIN et al., 2008).

Some physical properties of the product such as volume, density and porosity change with drying, which can alter the quality of these products. In case of soybeans, RIBEIRO et al. (2007) showed that with the reduction of seed moisture levels, the volume of the product decrease, but the seeds became more resistant to deformation.

There are several dryer types, which can be classified according to its agitation method, such as: static, rotary, with air circulation, fluid-vibration, among others. (CHIN et al., 2008; OMID et al., 2009; PARK et al., 2006; REINATO \& BORÉM, 2006). Currently, new techniques have been developed using solar energy, ultrasound and microwave energy (CHAVAN et al., 2008; CUI et al., 2008; FERNANDES \& RODRIGUES, 2008; GANESAPILLAI et al., 2008, JESUS, 2002), although the most common techniques are wood and gas (AFONSO JÚNIOR et al., 2006; REINATO \& BORÉM, 2006).

In drying of coffee, REINATO \& BORÉM (2006) compared the efficiencies of rotary dryers with wood and LPG as fuel. They observed that control of internal temperature of the dryer is best when using LPG as fuel, although both dryers achieve efficiency similar related to removal of moisture from coffee beans. For PARK et al. (2006), fluid-vibration dryers are options for drying granular materials, pellets, pastes and powders, and currently are being applied to clustering of milk powder, dry fertilizers, sugar, polymers zests, inorganic salts, pharmaceutical products, and asbestos fibers.

Depending on the technique used, the time required to complete the drying of agricultural products may take from several hours to days. To improve the efficiency of these techniques, considerable time and capital may be spent. Thus, modeling and simulation techniques allow the optimization of these processes in a timely and cost-effectively manner (DALPASQUALE \& SPERANDIO, 2010). There are several models that describe the kinetic behavior of moisture removal during any drying process, which shows the change in product mass with drying time. The more traditional models are: Page, Henderson-Henderson, Lewis, and Brooeker, obtained from the Arrhenius equation and Fick's Law (OLIVEIRA et al., 2006; PARK et al, 2006; PHOUNGCHANDANG et al., 2008; SIMAL et al., 2005). In addition, new models have been developed, as presented by DALPASQUALE \& SPERANDIO (2010), by ARAÚJO et al. (2009) and by SILVA et al. (2008b).

A new model that considers the enthalpy of the drying air constant was applied to the data of corn drying in thin layers by DALPASQUALE \& SPERANDIO (2010). The authors considered the saturation of the relative humidity as a necessary condition for the process to be adiabatic. The results showed the proposed model had good fit to the experimental data.

Normally, drying models consider the vaporization latent heat of water as a constant, but in reality it depends on the temperature of the environment. Based on this, SILVA et al. (2008b) developed a model that considers this dependence of latent heat with temperature to data from drying 'macassar' beans. Results showed that the model presented by the authors had good fit to the experimental data.

SANTANA et al. (2010) developed a drying model based on Newton's cooling law with modifications, as well as in the Fick's Law, so that the effective diffusivity was described. The 
model was presented as a combination of linear and exponential parameters. This model was applied to drying malted corn with good fit. BIAZUS et al. (2006a) also developed a model that combined drying parameters with the enzymatic activity of malted corn.

The $\alpha$ - and $\beta$-amylase enzymes are widely used by the beverage industry, especially in breweries; by textile industries, in tissue starching; by food industries to make biscuits, breads and other types of dough; by pharmaceutical companies to prepare clinical analysis kit; by the starch processing industries to obtain modified flour or glucose syrups, among others (BIAZUS et al., 2006a, 2006b; 2007, 2009 and 2010; SIVARAMAKRISHNAN et al., 2006). The search for purification methods of these enzymes in order to reduce costs has been extensively performed over the past years, since its price is estimated at US\$ 1,500 per gram of purified material. Thus, methods have recently been developed, such as expanded layer chromatography, membrane separation and two-phase aqueous systems (BIAZUS et al., 2006, 2007, 2010; SEVERO JÚNIOR et al., 2007; FERREIRA et al., 2007; TOLEDO et al., 2007). Its use has also been studied in ethanol production from cassava starch with the aim of supplementing the demand for this product, which is commonly produced from sugarcane (CURVELO-SANTANA et al., 2008, 2009 and 2010; LACERDA et al., 2008).

Normally, these enzymes are derived from barley malt or microorganisms, their temperatures and their optimal $\mathrm{pH}$ values ranging between $55^{\circ} \mathrm{C}$ and $75^{\circ} \mathrm{C}$ and 4.8 to 6.5 , respectively, depending on the origin (BIAZUS et al., 2009; CURVELO-SANTANA et al., 2008; SIVARAMAKRISHNAN et al., 2006). For preservation of the catalytic properties of enzymes in the malt corn for a long storage period, even after its use in various processes of starch hydrolysis, immobilization techniques were applied (SILVA et al., 2008a).

As barley is not grown in Brazil, this product is expensive. Thus, obtaining enzymes from corn (Zea mays) malt would make it an effective alternative to add value to this crop (BIAZUS et al., 2010; SILVA et al., 2008a). Therefore, the aim of this study is to determine kinetic parameters of moisture removal and obtain the optimal condition of malt corn drying in order to preserve the maximum activity of the $\alpha$ - and $\beta$-amylases in the final product.

Meta-heuristics techniques are powerful tools to solve complex optimization problems which search spaces for optimal solutions are too large to enable determining them accurately through deterministic method with acceptable processing time. These are methods that use information and insight about the problem to produce quick and good quality solutions. Among the meta-heuristics techniques that have emerged over the last decades, there are genetic algorithms (CEYLAN, 2008; CHAVES et al., 2007; GOLDBERG, 1989; THYAGARAJAN et al., 2000; ZHANG \& LU, 2006), Tabu Search and Simulated Annealing (KIRKPATRICK et al, 1983; PHAN \& PHAN, 1999). The latter was used in this work, because it is considered a promising alternative for solving optimization problems.

\section{METHODS}

\section{Seed germination}

Seeds were selected, weighed, washed and placed to absorb moisture up to $45 \%$ of its mass. They were then placed onto germination medium consisting of a layer of A3 filter paper covering a cotton layer $1.0 \mathrm{~cm}$ thick. The seeds were moistened every two hours and germination was stopped after the fourth day (BIAZUS et al., 2006a e 2009; CURVELO-SANTANA et al., 2008).

\section{Enzymatic assays}

During the drying process, the concentration of total protein and enzymatic activity in the dry malt was measured. The enzyme activity was determined according to Sandstedt, Kneen \& Blish (SKB method), as described by BIAZUS et al. (2007, 2008, 2009 and 2010) and TOLEDO et al. (2007). The enzyme activity unit in this case was the SKB, which indicates the amount of dextrinized starch per milligram of total protein in one hour. Total protein was measured according 
to the BRADFORD method (1976). To determine the specific enzymatic activity $\left(\boldsymbol{A} \boldsymbol{E}_{\boldsymbol{i}}\right)$ in the samples, the enzyme activity (in SKB) was divided by the total protein content (in $\mathrm{mg}$ ). With the enzyme activity measured in each dry sample, this was divided by the specific activity of the malt $\left(\boldsymbol{A} \boldsymbol{E}_{\boldsymbol{0}}\right)$, with the results presented dimensionlessly $(\boldsymbol{A} \boldsymbol{E})$.

\section{Conditions of the drying process}

Drying was conducted in a convective dryer with air circulation (FENTO brand, São Paulo, Brazil) with constant temperature, humidity $(65 \% \mathrm{RH})$ and airflow $\left(1.0 \mathrm{~m}^{3} / \mathrm{h}\right)$. A digital analytical scale BG 200 model provided by TECNAL (São Paulo, Brazil) was used for mass measurements. The malt was ground in a ball mill, BM model (VIATEST, Berlin, Germany) and dried at temperatures of $54{ }^{\circ} \mathrm{C}, 65^{\circ} \mathrm{C}$ and $76^{\circ} \mathrm{C}$, stored in plastic bags and kept at $5{ }^{\circ} \mathrm{C}$. These temperatures were chosen based on the amylase optimal temperature (BIAZUS et al., 2006a).

Germinated seeds were placed in watch glass (previously weighed and dried at work temperature), where their initial masses, or wet mass $\left(\boldsymbol{X}_{\boldsymbol{0}}\right)$, were measured. After each drying time, their dry weights $\left(\boldsymbol{X}_{\boldsymbol{i}}\right)$ were measured. To determine the initial grain moisture content, we used exposure to temperatures between $103{ }^{\circ} \mathrm{C}$ and $105^{\circ} \mathrm{C}$ for $40 \mathrm{~h}$ to $50 \mathrm{~h}$ of process. Equation 1 shows how to obtain the malt masses in dimensionless form $(\boldsymbol{X})$ and Equation 2 shows how to obtain the moisture content $\left(\boldsymbol{M}_{\boldsymbol{i}}\right)$ removed from the malt (BIAZUS et al., 2006a; OMID et al., 2009; PHOUNGCHANDANG et al., 2008; SANTOS \& SILVA, 2008; SIMAL et al., 2005).

$$
\mathrm{X}=\mathrm{X}_{\mathrm{i}} / \mathrm{X}_{0}
$$

For agricultural products, $R U=\frac{X_{i}-U E}{X_{0}-U E}$

RU - moisture ratio, dimensionless;

EU - moisture of equilibrium.

$$
M_{i}=\left(\frac{X_{0}-X_{i}}{X_{0}}\right) 100
$$

\section{Models of drying kinetics}

The drying kinetics curves were plotted from malt mass variation in dimensionless form (X) with drying time (t), described by Equations 3; 4;5 and 6, as shown in Table 1. The parameters of these equations are: $\mathrm{K}$, which is the drying kinetics constant; $\mathrm{A}$, which is the first empirical constant, being both constants derived from the Arrhenius equation (ARAÚJO \& LIBRANTZ, 2009; JESUS, 2002; OMID et al., 2009; PHOUNGCHANDANG et al., 2008; SANTOS \& SILVA, 2008; SIMAL et al., 2005). In addition to the aforementioned elements in the model proposed in this work, we have the following parameters: $M_{e}$, which is the moisture of equilibrium; $X_{e}$, which is the moisture in the end of the drying process, besides the parameter $\mathrm{K}$, already used in other models. Assessments of model adjustment were made by the methodology of analysis of variance (ANOVA) at 95\% confidence level (BARROS NETO et al., 2007).

TABLE 1. Equation models of drying kinetics.

\begin{tabular}{ccc}
\hline & Equations & Models \\
\hline (3) & $\mathrm{X}=\mathrm{Ae}^{-\mathrm{kt}}$ & BROOEKER et al. (1974) \\
(4) & $\mathrm{X}=\mathrm{A}\left(\mathrm{e}^{-\mathrm{kt}}+\frac{1}{9} \mathrm{e}^{-9 \mathrm{kt}}\right)$ & HENDERSON-HENDERSON (1968) \\
$(5)$ & $\mathrm{X}=\mathrm{e}^{-\mathrm{kt}^{\mathrm{n}}}$ & PAGE (SIMAL et al., 2008) \\
(6) & $\mathrm{X}=\mathrm{M}_{\mathrm{e}} \mathrm{e}^{-\mathrm{kt}}+\mathrm{X}_{\mathrm{e}}$ & SANTANA et al. (2010) \\
\hline
\end{tabular}




\section{Proceeding to apply Simulated Annealing}

Simulated Annealing (SA) is a local search technique that simulates the annealing process of metals, in which the metal is heated to high temperatures and then systematically cooled in the same order to achieve an equilibrium characterized by an orderly and stable microstructure. According to PHAM \& PHAM (1999), SA can also be defined as a probabilistic version of the hill-climbing algorithm. The pseudocode is shown in Figure 1.

\section{Start}

$s_{0}$ is the initial solution (randomly generated), $s$ is the solution represented by the current state, $s^{\prime}$ is the solution represented by the successor of the current state, $s^{*}$ is the best solution obtained so far, Iter is the counter of iteration number, Max_Iter is the maximum number of iterations, $\Delta E$ is the variation between $s$ and $s^{\prime}, P$ is the probability of accepting worse solutions than the current one, Temp is a temperature that controls probability $P$

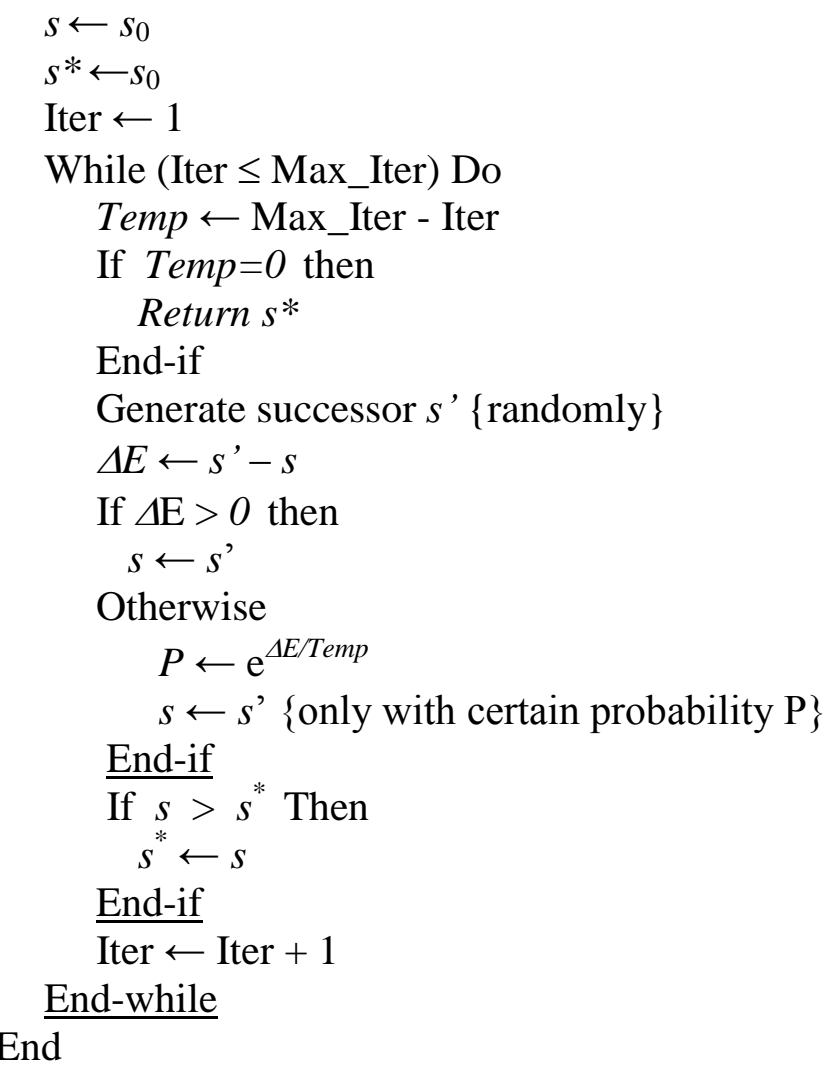

FIGURE 1. Pseudocode of Simulated Annealing.

In the SA technique, movements for states better than the current one is always accepted. If the movement is towards a deterioration state, it can be accepted with a certain probability, which is calculated taking into account the quality of movement $(\Delta \mathrm{E})$, which decreases according to the "temperature". Thus, in later iterations of the algorithm, only better solutions are accepted as the probability of accepting a worse solution is almost null (KIRKPATRICK et al., 1983; PHAN \& PHAN, 1999).

Equation 7 was used as an objective function in the simulated annealing technique to obtain the optimized parameters, which results are shown in Figure 1.

$$
\operatorname{LnAE}=-0.6886+0.0476 \mathrm{t}-1.4522 \mathrm{~T}-0.2910 \mathrm{t}^{2}+0.7437 \mathrm{~T}^{2}+0.5209 \mathrm{t} \mathrm{T}
$$

In the proposed problem, the simulated annealing technique was applied to determine $t$ and $T$ values that maximize $\operatorname{Ln} \boldsymbol{A E}$ (eq.7), with $t \in[5.18 ; 10.8]$ and $T \in\{54 ; 65 ; 76\}$. Thus, a state is represented by a pair of real values for $t$ and $T$, given the set of defined value . 


\section{RESULTS AND DISCUSSION}

\section{Seed drying}

Table 2 shows the mass values of malt in the dimensionless form in drying temperatures. As it can be seen in this table, the removal of moisture in the corn malt ranged between $40 \%$ and $42 \%$ $(\mathrm{w} / \mathrm{w})$ and high rate of moisture removal was achieved at $76{ }^{\circ} \mathrm{C}$ drying temperature. Since the initial moisture in the corn malt was $56.35 \%$, the final product showed $24.39 \%$ to $25.87 \%$ total moisture.

TABLE 2. Experimental data of drying isotherms.

\begin{tabular}{|c|c|c|c|c|c|}
\hline \multicolumn{6}{|c|}{ Drying Temperatures } \\
\hline \multicolumn{2}{|c|}{$54{ }^{\circ} \mathrm{C}$} & \multicolumn{2}{|c|}{$65^{\circ} \mathrm{C}$} & \multicolumn{2}{|c|}{$76^{\circ} \mathrm{C}$} \\
\hline$t(\mathrm{~h})$ & $X_{\text {exp }}$ & $t(\mathrm{~h})$ & $X_{\text {exp }}$ & $t(\mathrm{~h})$ & $X_{\exp }$ \\
\hline 0 & 1 & 0 & 1 & 0 & 1 \\
\hline 1 & 0.6822 & 1 & 0.6663 & 1 & 0.6950 \\
\hline 2 & 0.6493 & 2 & 0.6037 & 2 & 0.6408 \\
\hline 3 & 0.6227 & 3 & 0.6000 & 3 & 0.5844 \\
\hline 4 & 0.6136 & 4 & 0.5946 & 4 & 0.554 \\
\hline 5 & 0.5854 & 5.15 & 0.5775 & 5 & 0.5789 \\
\hline 6 & 0.5638 & 6 & 0.5635 & 6 & 0.5854 \\
\hline 7 & 0.5891 & 7 & 0.5833 & 7 & 0.5586 \\
\hline 8 & 0.5915 & 8 & 0.5796 & 8 & 0.6322 \\
\hline 9 & 0.5667 & 8 & 0.5787 & 9 & 0.5338 \\
\hline 10 & 0.5860 & 8 & 0.5802 & 10 & 0.5648 \\
\hline 11 & 0.6067 & 9 & 0.5781 & 11 & 0.5469 \\
\hline \multirow[t]{3}{*}{12} & 0.5773 & 10 & 0.5802 & 12 & 0.5888 \\
\hline & & 10.85 & 0.5900 & & \\
\hline & & 12 & 0.6027 & & \\
\hline
\end{tabular}

\section{Evaluation of drying models}

Table 3 shows the evaluation results of the adjustment models for drying temperatures at $54{ }^{\circ} \mathrm{C}, 65^{\circ} \mathrm{C}$ and $76{ }^{\circ} \mathrm{C}$, respectively. A detailed examination of this table shows that the ARAÚJO \& LIBRANTZ (2009) model showed the best $R$-values, i.e., it presented the best fit to the experimental data (BARROS NETO et al., 2007).

In the model proposed herein, the performance parameters $\left(X_{e}, M_{e}, K\right.$ and $\left.D_{e f}\right)$ and fitness function are obtained from the composition of the correlation coefficients $\left(\mathrm{R}^{2}\right)$. The proposed model performed well for the experimental data. The analytical model provided the effective moisture diffusivity due to the fact that the Page model (SIMAL et al., 2008) does not show a term for the equilibrium moisture content, as summarized in Table 3 . This table shows that $M_{e}, K$, and $D_{e f^{-}}$ values increased with the drying temperature. Values were found for the effective diffusivity of corn malt in a range of $4.410^{-10}$ to $-6.310^{-10} \mathrm{~m}^{2} \mathrm{~s}^{-1}$, being higher than those for white mulberry leaf, which ranged between 1.0.10 $10^{-10}$ and $-2.710^{-10} \mathrm{~m}^{2} \mathrm{~s}^{-1}$, and less than or equal to the values found for chicory roots, which had an interval between $3.5110^{-10}$ and $10.3610^{-10} \mathrm{~m}^{2} \mathrm{~s}^{-1}$ (CAI \& CHEN, 2008; CHIN et al., 2008; OLIVEIRA et al., 2006; PHOUNGCHANDANG et al., 2008). 
TABLE 3. Parameters and evaluation of adjustment quality.

\begin{tabular}{cccc}
\hline Drying Temperature & $54{ }^{\circ} \mathrm{C}$ & $65{ }^{\circ} \mathrm{C}$ & $76{ }^{\circ} \mathrm{C}$ \\
\hline Parameter & 0.7622 & Brooeker Model & 0.7562 \\
$\mathrm{~A}$ & 0.0322 & 0.7385 & 0.0346 \\
$\mathrm{~K}\left(\mathrm{~h}^{-1}\right)$ & 0.4317 & 0.0290 & 0.4197 \\
$\mathrm{R}^{2}$ & 0.3335 \\
\hline Parameter & Henderson-Henderson Model \\
\hline $\mathrm{A}$ & 0.7112 & 0.6895 & 0.7080 \\
$\mathrm{~K}\left(\mathrm{~h}^{-1}\right)$ & 0.0275 & 0.0250 & 0.0301 \\
$\mathrm{R}^{2}$ & 0.4974 & 0.3936 & 0.4869 \\
\hline Parameter & 0.1322 & 0.1425 \\
$\mathrm{~A}$ & 0.4055 & 0.0809 & 0.4175 \\
$\mathrm{~K}\left(\mathrm{~h}^{-1}\right)$ & 0.9784 & 0.4560 & 0.9373 \\
$\mathrm{R}^{2}$ & 0.9782 & 0.55721 \\
Parameter $_{\mathrm{X}}$ & 0.5898 & Pane Model & 0.4259 \\
$\mathrm{M}_{\mathrm{e}}$ & 0.4067 & 0.5545 & 0.8763 \\
$\mathrm{~K}^{-1} \mathrm{~h}^{2}$ & 0.7897 & 0.4152 & $6.3 \mathrm{e}-10$ \\
$\mathrm{D}_{\mathrm{ef}}\left(\mathrm{m}^{2} / \mathrm{s}\right)$ & $5.5 \mathrm{e}-10$ & 0.6274 & 0.9569 \\
$\mathrm{R}^{2}$ & 0.9750 & $4.4 \mathrm{e}-10$ &
\end{tabular}

\section{Behavior of the drying kinetics}

The experimental data and prediction by the SANTANA et al. (2010) model are presented in the drying isotherm shown in Figure 2. The curve is asymptotic to the time axis between the third and fourth hours of drying and moisture removal percentage was around $43 \%$, with maximum temperature close to $45 \%$ at $75{ }^{\circ} \mathrm{C}$.

In drying processes of common food products, this fact would indicate that the temperature established as optimal for drying corn malt, since the lower the moisture in the product the lower the chance of contamination and damage by microorganisms. However, the enzymatic activity is also an important parameter for evaluating quality and marketability of corn malt.

Since 40-45\% moisture were added to the corn seed for malt production, the drying curves have a particular behavior, which occurred in three steps: 1) it corresponds to the surface of the seed moisture and volatile gasses, this moisture is easily removed; 2) it includes the moisture that is in the internal layers and the 'natural' moisture of corn seeds (from 11.35 to $16.35 \% \mathrm{w} / \mathrm{w}$ ); and 3) it encompasses the 'natural' moisture in innermost layers, the so-called link equilibrium moisture, which has a high the high degree of difficulty of withdrawal.

$\boldsymbol{K}$ and $\boldsymbol{A}$ constant values were highest at $76{ }^{\circ} \mathrm{C}$, which shows that in the highest temperature studied the moisture desorption rate was higher than in other temperature studies. This can also be observed when comparing the drying curves presented in Figure 1. This increased moisture removal occurs, probably due to high temperature, promoting the volatilization of other components (e.g., terpenoids, alkaloids), as well as other components pulled along with the water vapor, which causes the apparent reduction of moisture equilibrium (BIAZUS et al., 2006a; OMID et al., 2009; PHOUNGCHANDANG et al., 2008; SANTOS \& SILVA, 2008; SIMAL et al., 2005). 


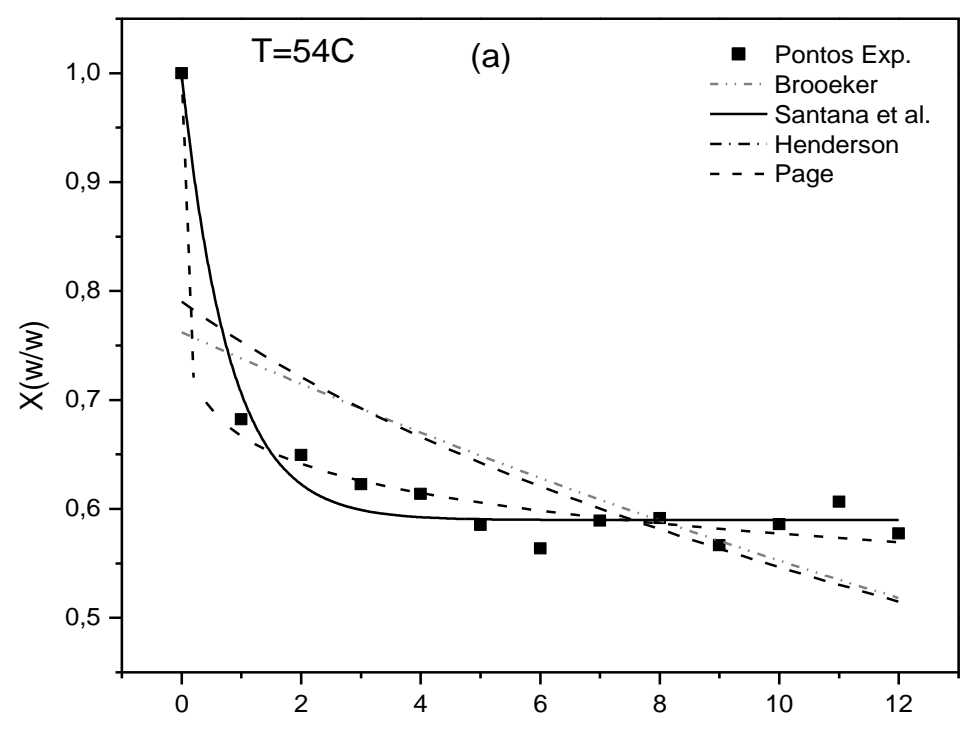

$\mathrm{t}(\mathrm{h})$

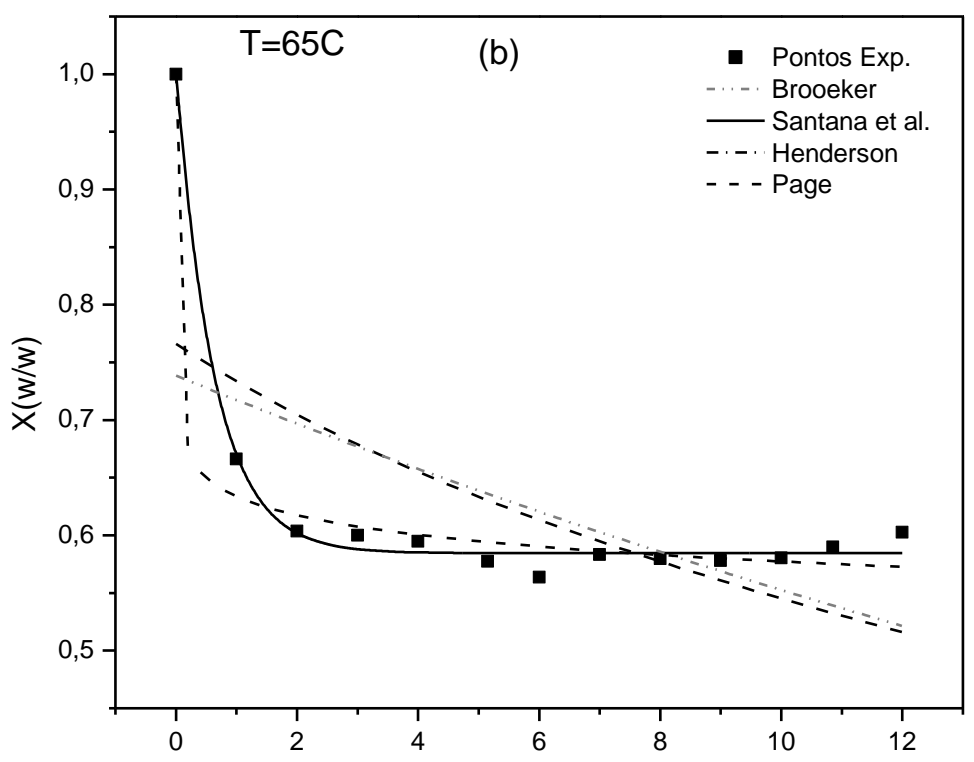

$\mathrm{t}(\mathrm{h})$

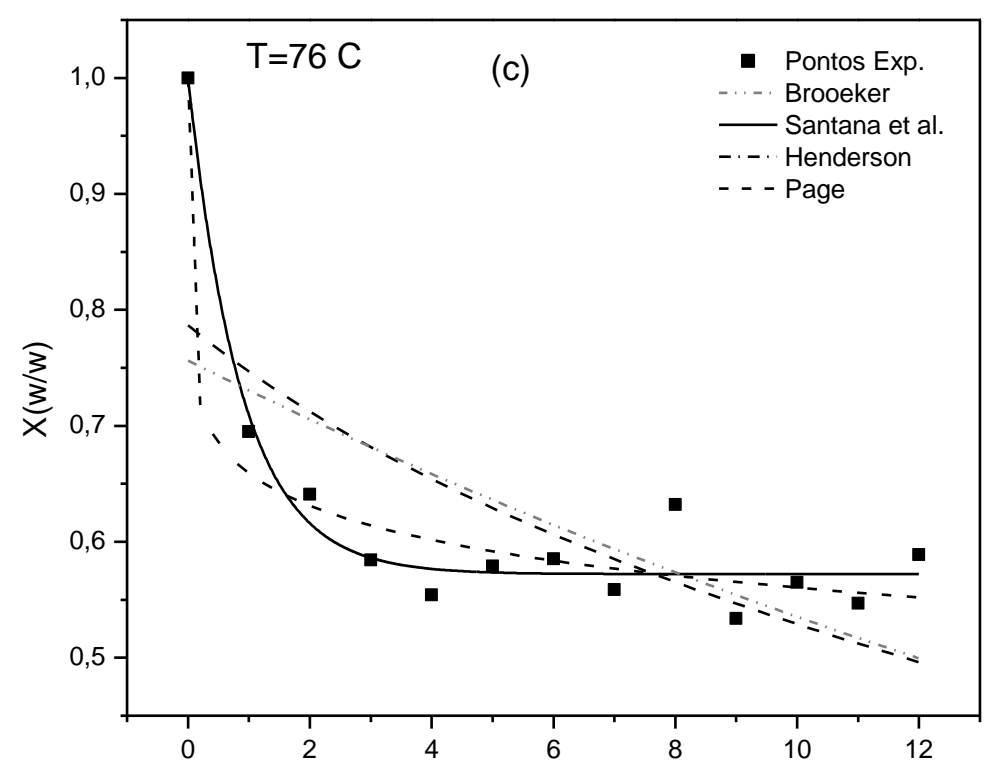

$t(h)$

FIGURE 2. Drying curves of corn malt for temperatures of (a) $54{ }^{\circ} \mathrm{C}$, (b) $65{ }^{\circ} \mathrm{C}$ and (c) $76{ }^{\circ} \mathrm{C}$. 
Comparison amongst models showed that the model by SANTANA et al. (2010), the SA model proposed in this work, and the Page model (SIMAL et al., 2008) showed the best adjustments to experimental data compared to Brooeker (BROOEKER et al., 1974) and HendersonHenderson (Henderson and Henderson, 1968) models, because the values of $\mathrm{R}^{2}$ are close to 1.0, while the $\mathrm{R}^{2}$ values presented by the other model were smaller than 0.5 . This is shown in Table 3, which reports the parameters and correlation coefficients obtained for the proposed models.

For corn stalk and wheat straw, CAI \& CHEN (2008) observe good adjustment for all standard models, and especially the Page model, with $\mathrm{R}^{2}=0.999$. CEYLAN (2008) showed that the Artificial Neural Network (ANN) is a good tool for simulating the drying process, and this technique proved to be best adjusted than classic models for the drying of pinewood.

However, the model proposed here showed better performance for experimental data than the classical models, since it considered that the curves are of drying kinetics model functions of mass transfer mixed model, as observed by CHIN et al. (2008), PHOUGCHANDANG et al. (2008) and SOBIESKI (2008).

\section{Optimizing the drying process}

Table 4 shows experimental values of enzyme activity obtained for each corn malt drying assay (the results are averages of the analysis in triplicate). Table 5 shows evaluation results of the empirical model adjustment that best fits the drying process of corn malt, under the conditions studied. Since the results of the F-test (3.47) and correlation $(\boldsymbol{R}=0.9934)$ are close to the optimum values cited in the literature (BARROS NETO et al., 2007), one could say that the model represented by Equation 6 is adjusted to the experimental data. The model that was best adjusted showed a quadratic effect of time $(\boldsymbol{t})$ and drying temperature $(\boldsymbol{T})$ on the enzyme activity $(\boldsymbol{A} \boldsymbol{E})$ in a natural logarithm function.

TABLE 4. Experimental data of malt enzymatic activity to optimize the drying process. $A E$ is the enzyme activity of the dry malt by activity of moist mal.

\begin{tabular}{cccc}
\hline Assays & $t(\mathrm{~h})$ & $T\left({ }^{\circ} \mathrm{C}\right)$ & $A E$ \\
\hline 1 & 6 & 54 & 6.684 \\
2 & 10 & 54 & 1.710 \\
3 & 6 & 76 & 0.1292 \\
4 & 10 & 76 & 0.2656 \\
5 & 8 & 65 & 0.4822 \\
6 & 8 & 65 & 0.4522 \\
7 & 8 & 65 & 0.5851 \\
8 & 5.18 & 65 & 0.2571 \\
9 & 10.8 & 65 & 0.3097 \\
\hline
\end{tabular}

TABLE 5. Evaluation of model adjustment of the model that best fitted to the optimization of the drying process, by using ANOVA method.

\begin{tabular}{cccccc}
\hline Source of & Quadratic Sum & $\begin{array}{c}\text { Degrees of } \\
\text { Freedom }\end{array}$ & Quadratic Mean & $F_{\text {calc }}$ & $F_{\text {tab }}$ \\
\hline Regriation & 10.981 & 5 & 2.196 & 31.269 & 9.01 \\
Residues & 0.211 & 3 & 0.070 & & \\
Total & 11.118 & 8 & & & \\
& Coefficient de Correlation $(R)=0,9938$ & & & \\
\hline
\end{tabular}

We applied the simulated annealing technique to obtain optimized parameters, by using Equation 7 as the objective function, and the results are shown in Figure 1. Accordingly, the temperature of $54{ }^{\circ} \mathrm{C}$ was considered optimal for drying corn malt, because the enzyme activity was significantly higher than those found for other temperatures. The maximum point was found for drying time of around 6 hours. It shows sharp decrease in the value of $\operatorname{Ln} \boldsymbol{A} \boldsymbol{E}$ for high values of drying time. 
Figure 3 shows actual values of enzyme activity $(\boldsymbol{A} \boldsymbol{E})$ obtained by converting the results of the Simulated Annealing for the drying temperatures used in this work. As it can be seen, enzyme activity for the temperatures of $65{ }^{\circ} \mathrm{C}$ and $76^{\circ} \mathrm{C}$ are lower than that obtained at $54{ }^{\circ} \mathrm{C}$, indicating the latter temperature is most suitable for the drying process of corn malt.

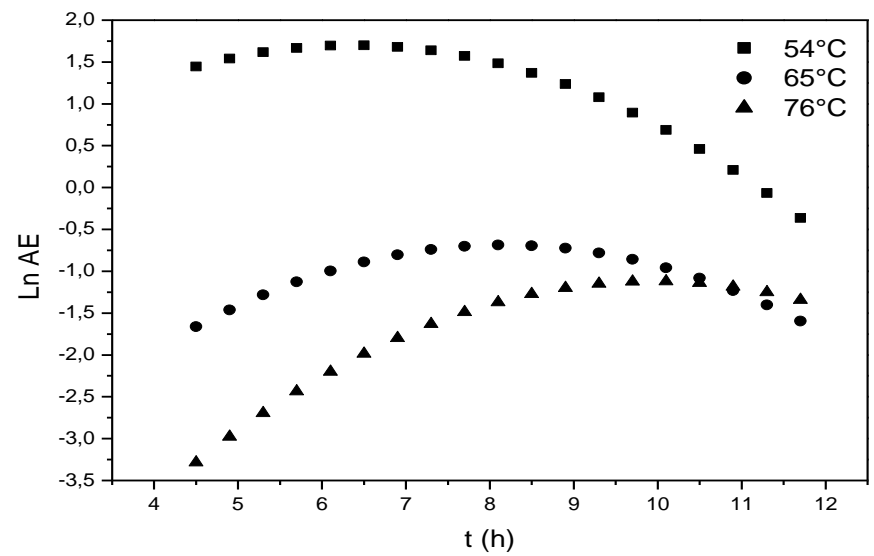

FIGURE 3. Simulation of the enzyme activity variation in a logarithmic function with drying time, for temperatures of $54{ }^{\circ} \mathrm{C}, 65^{\circ} \mathrm{C}$ and $76{ }^{\circ} \mathrm{C}$.

In drying processes, it is necessary that the final product shows reduced moisture in its interior, so that contamination by microorganisms is avoided, thus preserving it for a longer time (shelf life) and in the case of malt, maintaining good enzyme activity. Figure 4 combines the results of kinetics of enzyme activity during drying at $54{ }^{\circ} \mathrm{C}$ for the optimization process.

Figure 4 shows the behavior of enzyme activity and moisture content along the drying process; it is verified that drying corn malt for a long time is not necessary. According to SA simulation, the optimal condition for drying corn malt occurred at $54{ }^{\circ} \mathrm{C}$ for between $5.6 \mathrm{~h}$ and $6.4 \mathrm{~h}$ of drying, AE values of the corn malt were around $5.26 \pm 0.06 \mathrm{SKB} / \mathrm{mg}$ protein and $15.69 \pm 0.10 \%$ moisture, for the experimental conditions of this work. SA results are similar to those obtained by BIAZUS et al. (2006a), who optimized the process of drying the corn malt as being between $5.2 \mathrm{~h}$ and $6 \mathrm{~h}$ at $54{ }^{\circ} \mathrm{C}$, from the methodology of response surface.

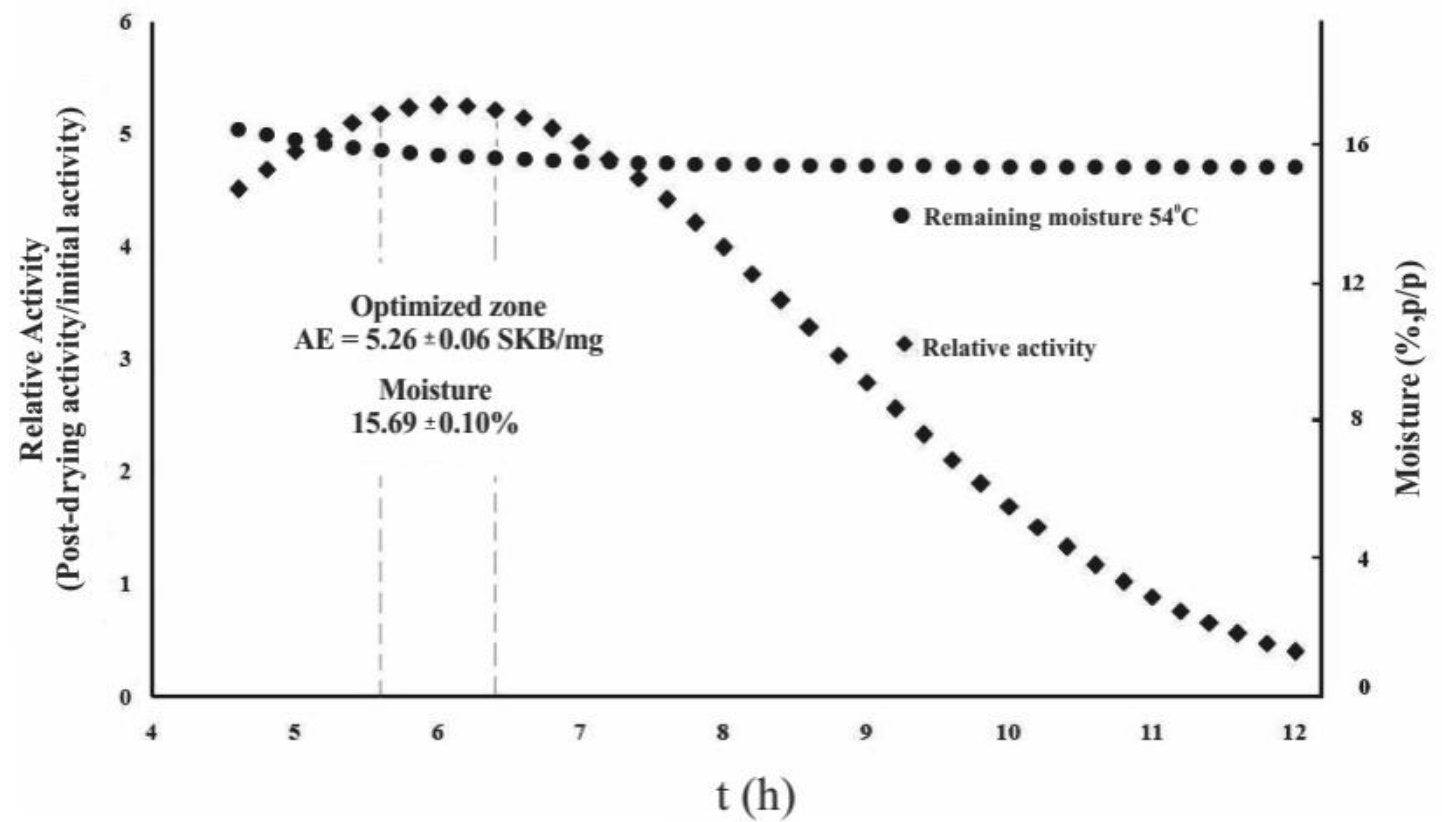

FIGURE 4. Prediction of the real variation of enzyme activity along the drying process at $54{ }^{\circ} \mathrm{C}$, according to the Simulated Annealing method. 


\section{CONCLUSIONS}

The drying isotherms showed asymptotic behavior with the time axis, where it was observed that the moisture removal rate remained constant between the third and fifth hour of the process, eliminating more than $44 \%$ of the moisture.

Among the models studied, the SANTANA et al. (2010) was the model that best adjusted to the experimental data. The values of the drying constant, $K$, the empirical constant of moisture balance, $M_{e}$ and the empirical moisture constant at the end of the drying process, $X_{e}$, ranged from $0.7897-0.8763 \mathrm{~h}^{-1}, 0.4067-0.4259$ and $0.5898-0.55721$, respectively.

The dependence analysis of enzyme activity $(\boldsymbol{A E})$ over time $(\boldsymbol{t})$ and the drying temperature $(\boldsymbol{T})$ showed that there is a greater influence of temperature than the drying time, and that the process should be performed at $54{ }^{\circ} \mathrm{C}$ and for $5.6 \mathrm{~h}$ and $6.4 \mathrm{~h}$ of drying time, according to the result obtained from the simulation using the simulated annealing technique, so that the malt keep a good enzyme activity. Respective values found for specific activity and remaining moisture were $5.26 \pm$ $0.06 \mathrm{SKB} / \mathrm{mg} 15.69 \pm 0.10 \%$ in the corn malt.

\section{ACKNOWLEDGEMENTS}

The authors acknowledge Uninove for the financial support and CAPES for granting the scholarship.

\section{ABBREVIATIONS}

$\boldsymbol{A}$ - Empirical constant (dim.)

$\boldsymbol{A} \boldsymbol{E}$ - Enzyme activity ([SKB/mg proteins] / [SKB/mg proteins])

$\boldsymbol{B}$ - Empirical Constant (dim.)

$\boldsymbol{F}_{\text {Calc }}$ - Calculated value of $\boldsymbol{F}$-test (dim.)

$\mathbf{F}_{\text {tab }}$ - Table value of $\boldsymbol{F}$-test (dim.)

$\boldsymbol{i}$ - Variable values along time (dim.)

$\boldsymbol{K}$ - Drying constant (h-1)

$\boldsymbol{t}$ - Drying time (h)

$\boldsymbol{M}$ - Moinsten mass (dim.)

$\boldsymbol{X}$ - Dry mass (dim.)

$\boldsymbol{X}_{\boldsymbol{i}}$ - Dry mass in drying assays $(\mathrm{g})$

$\boldsymbol{X}_{\boldsymbol{0}}$ - Initial Moisten mass (g)

$\boldsymbol{x}_{1}$ and $\boldsymbol{x}_{2}$ - Coded variables (dim.)

dim. - Dimensionless

\section{REFERENCES}

AFONSO JÚNIOR, P.C.; OLIVEIRA FILHO, D.; COSTA, D.R. Viabilidade econômica de produção de lenha de eucalipto para secagem de produtos agrícolas. Engenharia Agrícola, Jaboticabal, v.26, n.1, p.28-35, 2006.

ARAÚJO, S.A.; LIBRANTZ, A.F.H. Algoritmos Genéticos aplicados na simulação do processo de produção do malte de milho, In: ENCONTRO NACIONAL DE ENGENHARIA DE PRODUÇÃO, 29., 2009, Salvador. Anais...

BARROS NETO, B.; SCARMINIO, I.S.; BRUNS, R.E. Campinas: Como fazer experimentos: pesquisa e desenvolvimento na ciência e na indústria. 3.ed. Editora da UNICAMP, 2007. v.1. 480 p.

BIAZUS, J.P.M.; SANTANA, J.C.C.; SOUZA, R.R.; TAMBOURGI, E.B. Purificação de amilases de malte de Zea mays. Ciencia e Tecnologia de Alimentos, Campinas, v.30, n.1, p.218-223, 2010. 
BIAZUS, J.P.M.; SOUZA, R.R.; MARQUEZ, J.E.; FRANCO, T.T.; SANTANA, J.C.C.; TAMBOURGI, E.B. Production and characterization of amylases from Zea mays malt. Brazilian Archive of Biology and Technology, Curitiba, v.52, n.4, p.991-1000, 2009.

BIAZUS, J.P.M.; SANTANA, J.C.C.; SOUZA, R.R.; JORDÃO, E.; TAMBOURGI, E.B. Continuous extraction of $\alpha$ - and $\beta$-amylases from Zea mays malt in a PEG4000/CaCl 2 ATPS. Journal of Chromatography B, Amsterdam, v.858, n.1-2, p.277-233, 2007.

BIAZUS, J.P.M.; SOUZA, R.R.; CURVELO-SANTANA, J.C.; TAMBOURGI, E.B. Otimização da secagem do malte de Zea mays. Ciência e Tecnologia de Alimentos, Campinas, v.26, n.4, p.787792, 2006a.

BIAZUS, J.P.M.; SEVERO JR., J.B.; SANTANA, J.C.C.; SOUZA, R.R.; TAMBOURGI, E.B. Study of amylases recovery from maize malt by ion-exchange expanded bed chromatography. Process Biochemistry, London, v.41, p.1786-1791, 2006b.

BRADFORD, M.M. A Rapid and sensitive method for the quantitation of microgram quantities of protein. Utilizing the principle of protein-dye binding. Analytical Biochemistry, New York, v.72, p.248-254, 1976.

BROOEKER, D.B.; BAKKER-ARKEMA, F.W.; HALL, C.W. Drying cereal grains. Westport: The Avi Publishing, 1974.

CAI, J.; CHEN, S. Determination of drying kinetics for biomass by thermogravimetric analysis under nonisothermal condition. Drying Technology, New York, v.26, n.12, p.1464-1468, 2008.

CEYLAN, I. Determination of drying characteristics of timber by using artificial neural networks and mathematical models. Drying Technology, New York, v.26, n.12, p.1469-1476, 2008.

CHAVAN, B.R.; YAKUPITIYAGE, A.; KUMAR, S. Mathematical modeling of drying characteristics of Indian mackerel (Rastrilliger kangurta) in solar-biomass hybrid cabinet dryer. Drying Technology, New York, v.26, n.12, p.1552-1562, 2008.

CHAVES, A.A.; BIAJOLI, F. .; MINE, O. .; SOUZA, M.J.F. Metaheurísticas híbridas para resolução do problema do caixeiro viajante com coleta de prêmios. Revista Produção, São Paulo, v.17, n.2, p.263-272, 2007.

CHIN, S.K.; LAW, S.L.; SUPRAMANIAM, C.V.; CHENG, P.G.; MUJUMDAR, A.S. Convective drying of Ganoderma tsugae Murrill and effect of temperature on basidiospores. Drying Technology, New York, v.26, n.12, p.1524-1533, 2008.

CUI, Z.-W.; LI, C.-Y.; SONG, C.-F.; SONG, Y. Combined microwave-vacuum and freeze drying of carrot and apple chips. Drying Technology, New York, v.26, n.12, p.1517-1523, 2008.

CURVELO-SANTANA, J.C.; EHRHARDT, D.D.; TAMBOURGI, E.B. Otimização da produção de álcool de mandioca. Ciência e Tecnologia de Alimentos, Campinas, v.30, n.3, p.613-617, 2010.

CURVELO-SANTANA, J.C.; LIBRANTZ, A.F.H.; TAMBOURGI, E.B. Approach model for simulation of the starch hydrolysis by $\alpha$-amylase and alcohol production from manioc root starch. Chemical Product and Process Modeling, v.4, n.4, Art.13, 2009.

CURVELO-SANTANA, J.C.; FERREIRA, G.B.; BIAZUS, J.P.M.; SOUZA, R.R.; TAMBOURGI, E.B. Biochemistry characterization of $\alpha$ - and $\beta$-amylases from Zea mays malt and statistical analysis approach of the degradation of Manioc Starch. Journal of Food Process Engineering, Westport, v.31, p.649-710, 2008.

DALPASQUALE, V.A.; SPERANDIO, D., Modelo de simulação de secagem de produtos agrícolas usando entalpia do ar constante. Engenharia Agrícola, Jaboticabal, v.30, n.4, p.726-731, 2010.

FERREIRA, G.F.; EVANGELISTA, A.F.; SEVERO JUNIOR, J.B.; SOUZA, R.R.; SANTANA, J.C.C.; TAMBOURGI, E.B.; ELIZABETE, J. Partitioning optimization of proteins from Zea mays 
malt in ATPS PEG 6000/CaCl 2 . Brazilian Archives of Biology and Tecnnology, Curitiba, v.50, n.3, p.567-564, 2007.

FERNANDES, F.A.N.; RODRIGUES, S. Application of ultrasound and ultrasound-assisted osmotic dehydration in drying of fruits. Drying Technology, New York, v.26, n.12, p.1509-1516, 2008.

GANESAPILLAI, M.; REGUPATHI, I.; MURUGESAN, T. Characterization and process optimization of microwave drying of plaster of Paris. Drying Technology, New York, v.26, n.12, p.1484-1496, 2008.

GOLDBERG, D.E. Genetic algorithms in search, optimization, and machine learning . Massachusetts: Addison-Wesley Pub, 1989.

HENDERSON, J.M.; HENDERSON, S.M.A computacional procedure for deep-bed drying analysis. Journal of Agricultural Engineering Research, London, v.13, p.87-95, 1968.

JESUS, S.S. Desenvolvimento e análise do processo de secagem de $\alpha$-amilase por microondas a vácuo. 150 f. 2002. Dissertação (Mestrado) - Faculdade de Engenharia Química, Universidade Estadual de Campinas, Campinas, 2002.

LACERDA, L.G.; AZEVEDO, J.A.M.; CARVALHO FILHO, M.A.S.; DEMIATE; I.M.; SCHNITZLER, E.; VANDENBERGHE, L.P.S.; SOCCOL, C.R.S. Thermal characterization of partially hydrolyzed cassava (Manihot esculenta) starch granules. Brazilian Archives of Biology Technology, v.51, n.6, p.1209-1216, 2008.

KIRKPATRICK, S.; GELATT JR., C.D.; VECCHI, M.P. Optimization by simulated annealing, Science, v. 220, n.4598, p.671-680, 1983.

OLIVEIRA, R.A.; OLIVEIRA; W.P.; PARK, K.J. Determinação da difusividade efetiva de raiz de chicória. Engenharia Agrícola, v.26, n.1, p.181-189, 2006.

OMID, M.; BAHARLOOEI, A.; AHMADI, H. Modeling drying kinetics of pistachio nuts with multilayer feed-forward neural network. Drying Technology, New York, v.27, n.10, p.1069-1077, 2009.

PARK, K.J.; BROD, F.P.R.; OLIVEIRA, R.A. Transferência de massa e secagem em leitos vibrofluidizados - uma revisão. Engenharia Agrícola, Jaboticabal, v.26, n.3, p.840-855, 2006.

PHAM, D.T.; PHAM, P.T.N. Artificial intelligence in engineering. International Journal of Machine Tools \& Manufacture, v.39, n.6, p.937-949, 1999.

PHOUNGCHANDANG, S.; TOCHIP, L.; SRIJESDARUK, V. White mulberry leaft drying by heat pump dehumidified dryers. World Journal of Agricultural Science, v.4, Special, p.844-851, 2008.

REINATO, C.H.R.; BORÉM, F.M. Variação da temperatura e do teor de água do café em pó em secador rotativo usando lenha e GLP como combustíveis. Engenharia Agrícola, Jaboticabal, v.26, n.2, p.561-569, 2006.

RIBEIRO, D.M.; CORRÊA, P.C.; FURTADO, B.F.; GONELI, A.L.D.; RESENDE, O. Propriedades mecânicas dos grãos de soja em função do teor de água. Engenharia Agrícola, Jaboticabal, v.27, n.2, p.493-500, 2007.

SANTANA, J.C.C.; ARAÚJO, S.A.; LIBRANTZ, A.F.H.; TAMBOURGI, E.B. Optimization of the corn malt drying by use of genetic algorithm. Drying Technology, New York, v.28, n.11, 1236$1244,2010$.

SANTOS, P.H.S.; SILVA, M. Retention of vitamin C in drying processes of fruits and vegetables A review. Drying Technology, New York, v.26, n.12, p.1421-1437, 2008.

SEVERO JÚNIOR, J.B.; OLIVEIRA, L.S.S.; SARDEIRO, F.S.; SOUZA, R.R.; LOPES, F.L.G.; SANTANA, J.C.S.; TAMBOURGI, E.B. Response surface methodology to evaluation the recovery 
of amylases by hollow fiber membrane. Brazilian Archives of Biology and Tecnology, Curitiba, v.50, n.4, p.713-718, 2007.

SILVA, R.L.F.O.B.; SOUZA, R.R.; SANTANA, J.C.C.; TAMBOURGI, E.B. Imobilização de enzimas de milho maltado em gel. Ciência e Tecnologia de Alimentos, Campinas, v.28, n.3, p.642648, 2008.

SILVA, W.P.; SILVA, C.M.D.P.S.; PRECKER, J.W.; SILVA, D.D.P.S. Influência da temperatura do ar de secagem no calor latente de vaporização de água em feijão macassar (Vigna unguiculata (L.) Walp.), variedade sempre-verde. Engenharia Agrícola, Jaboticabal, v.28, n.2, p.315-324, 2008b.

SIMAL, S.; FEMENIA, A.; GARAU, M.C.; ROSSELLÓ, C. Use of exponential, Page's and diffusional models to simulate the drying kinetics of kiwi fruit. Journal of Food Engineering, Essex, v.66, n.3, p.323-328, 2005.

SIVARAMAKRISHNAN, S.; GANGADHARAN, D.; NAMPOOTHIRI, D.K.; SOCCOL, C.R.; PANDEY, A. $\alpha$-Amylases from microbial sources - An overview on recent developments. Food Technology and Biotechnology, Zagreb, v.44, n.2, p.173-184, 2006.

SOBIESKI, W. Numerical analysis of sensitivity of Eulerian multiphase model for a spouted-bed grain dryer. Drying Technology, New York, v.26, n.12, p.1438-1456, 2008.

THYAGARAJAN, T.; SHANMUGAMM, J.; PONNAVAIKKO, M.; PANDA, R.C. Hybrid intelligent control scheme for air heating system using fuzzy logic and genetic algorithm. Drying Technology, New York, v.18, n.1, p.165-184, 2000.

TOLEDO, A.L.; SEVERO JR., J.B.; SOUZA, R.R.; CAMPOS, E.S.; SANTANA, J.C.C.; TAMBOURGI, E.B. Purification by expanded bed adsorption and characterization of an $\alpha-$ amylases FORILASE NTL® from A. níger. Journal of Chromatography B, Amsterdam, v.846, n.12, p.51-56, 2007.

ZHANG, C.; LU, Y. The improved ant colony algorithm based on immunity system genetic algorithm and application. In: IEEE INTERNATIONAL CONFERENCE OF COGNITIVE INFORMATICS, 5., 2006. Proceedings... v.2, p.726-731. 